\title{
Notes on two lichenicolous Epigloea species from Central Europe
}

\author{
Paweł Czarnota*, Emil Hernik \\ Department of Agroecology, University of Rzeszów, Ćwiklińskiej 2, 35-601 Rzeszów, Poland
}

\section{Abstract}

Taxonomic remarks, known distribution, ecological notes and new records in Central Europe for two species of Epigloea are provided. Many specimens recognized here under E. soleiformis characterize slightly wider and more ellipsoid ascospores than those described in the protologue but they are regarded as some kind of a phenetic variability of this species. E. soleiformis seems to be not only algicolous fungus but also facultatively lichenicolous on Placynthiella spp. and terricolous Peltigera spp. while E. urosperma is found to be exclusively lichenicolous on Placynthiella dasaea. E. soleiformis is new for the Western Carpathians and the Harz Mts, and E. urosperma is new for whole Carpathians.

Keywords: Ascomycota, taxonomy, algicolous fungi, lichenicolous fungi, lichens, Poland, Germany

\section{Introduction}

The genus Epigloea Zukal containing 12 species [1] belongs to the family Epigloeaceae (Zahlbr.) of uncertain taxonomic position within Ascomycota [2]. All of known Epigloea species are probably under-collected due to their inconspicuousness, ephemeral ascomata and specific niche requirements. Most of these microfungi live as a fine mycelium immersed in the gelatinous algal film. These algal films cover bare damp soils, rocks, rotten wood as well as plant debris (especially moribund bryophytes) and various terricolous and epibryophytic lichens. The biological nature of the algicolous lifestyle of Epigloea spp. remains poorly understood. They were described as lichens, "semi-lichens" or non-lichenized parasites of algae or their commensals [3-7]. Lichenicolus records (without the algal film) were very rare. Almost all of them referred to the lichen parasite - E. urosperma [6-8]. E. soleiformis has been reported as a lichenicolous, weakly parasitic fungus only from two localities in Asia [9] and from N Poland [10].

From the Carpathians only several reports on Epigloea are known, one of Epigloea medioincrassata (Grummann) Döbbeler from Polish part of the Tatra Mts [11], one of E. pleiospora Döbbeler from the Bieszczady Mts [12] and one of E. soleiformis Döbbeler from the Ukrainian Eastern Carpathians [13].

The aim of this paper is to present some additional data that would contribute to the knowledge of the genus Epigloea and

* Corresponding author. Email: pawczarnota@poczta.onet.pl

Handling Editor: Zygmunt Dajdok

This is an Open Access digital version of the article distributed under the terms of the Creative Commons Attribution 3.0 License (creativecommons.org/licenses/by/3.0/), which permits redistribution, commercial and non-commercial, provided that the article is properly cited. the distribution of its two representatives in Central Europe with special remarks on the intraspecific variability within $E$. soleiformis.

\section{Material and methods}

Material was collected occasionally by the first author during several recent field trips in different regions of Poland and the Harz Mts in Germany. Results of field explorations of lichenicolous microlichens, mainly on terricolous Placynthiella spp. and Peltigera spp. carried out in 2005 and 2012 by the second author in the Wyżyna Śląsko-Krakowska upland geographical macroregion [14] have been included as well.

Fungi were identified by standard microscopy. Apothecial hand-made sections were mounted in water and sometimes in $\mathrm{KOH}$ or $\mathrm{HNO}_{3}$ for better view of the size of investigated internal structures, especially ascospores. Details of anatomy were measured in water. Nomenclature of taxa follows MycoBank fungal databases [1].

Distributional, ecological and taxonomic notes have been included.

Specimens collected by P. Czarnota are deposited in the herbarium of the Gorce National Park (GPN) and by E. Hernik in the herbarium of Rzeszów University (RES) and his private herbarium.

\section{Results}

\section{Epigloea soleiformis Döbbeler}

Beih Nova Hedwigia 79: 229.1984. Fig. 1a-e.

DIAGNOSTIC CHARACTERS. Description based on examined specimens only. Mycelium in membrane-like, dull green, gelationous, very thin algal film, composed of loosely distributed Coccomyxa algae. Alga cells penetrated by fungus 
haustoria. Perithecioid ascomata partly immersed in the algal film or sometimes directly on the thallus of the lichen host (then mycelium invisible), 0.1-0.15 $\mathrm{mm}$ diam., globose, dull blackish green, surrounded by a thin, colorless, non-algal coat. Vertical section colorless except for the upper part of excipulum, which is dull green. Hamathecium of simple, thin paraphyses. Asci 8-spored, cylindrical, 9-11 × 40-50 $\mu \mathrm{m}$. Ascospores 1-septate, ellipsoid, sometimes ovoid, not or only slightly constricted in the middle part, $4-5.5(-6) \times$ (9-)10-13(-14) $\mu \mathrm{m}$. Pycnidia not seen. For detailed illustrated description see Döbbeler [3].

NOTES. The new findings presented below characterize rather ellipsoid or only slightly ovoid ascospores almost exclusively lacking median constriction (Fig. 1c). They are usually slightly wider than described as typical in the protologue [3]. Kukwa et al. [10] gave similar description of two specimens from N Poland. Döbbeler [3] mentioned in his comment to the protologue of E. soleiformis that some revised Grummann's specimens from Bavaria had no median constriction usually observed in other specimens. He suggested that such specimens may represent some separate kind of a phenetic variability within this species and could be regarded under some intraspecific taxonomic level. The variability of the shape of ascospores of E. soleiformis found in different regions of Europe is presented by the following authors: Döbbeler [3] (plate 11,1-3), Ceynowa-Giełdon [4] (Fig. 8c), Pérez-Ortega and Barreno [6] (Fig. 1d). Moreover, Zhurbenko [9] in Russian specimens of E. soleiformis found ascospores which were not exclusively 1-septate but also occasionally simple.

Epigloea renitens (Grumm.) Döbbeler has a closest phenetic affinity to E. soleiformis. Döbbeler [3] showed that both species differ in the size of ascocarps, asci and ascospores; $E$. soleiformis forms smaller perithecioid ascomata $(70-150 \mu \mathrm{m}$ vs. $105-220 \mu \mathrm{m}$ in E. renitens) and its ellipsoid spores are also smaller and usually with median constriction while ascospores of E. renitens are mainly ovoid, slightly aciculate [6] and usually have distinctly larger one cell. In the description and pictures included by Döbbeler [3] we can find, however, some ascospores of both species completely similar to each other in their size and shape (distinctly ellipsoid and not constricted). Thus, the basic question - how is the real delimitation of both taxa? - seems to be unresolved, more so as an examination of the types of both species was not available by authors in recent time. Due to the lack of molecular evidences supporting the delimitation of different lineages confined to some phenetic characters of both taxa we propose to keep separately E. renitens and E. soleiformis, the later being the variable species characterized both constricted and not constricted ascospores, reaching $5.5 \mu \mathrm{m}$ width. It is not excluded, however, that collections presented here represent some new species within the genus Epigloea.
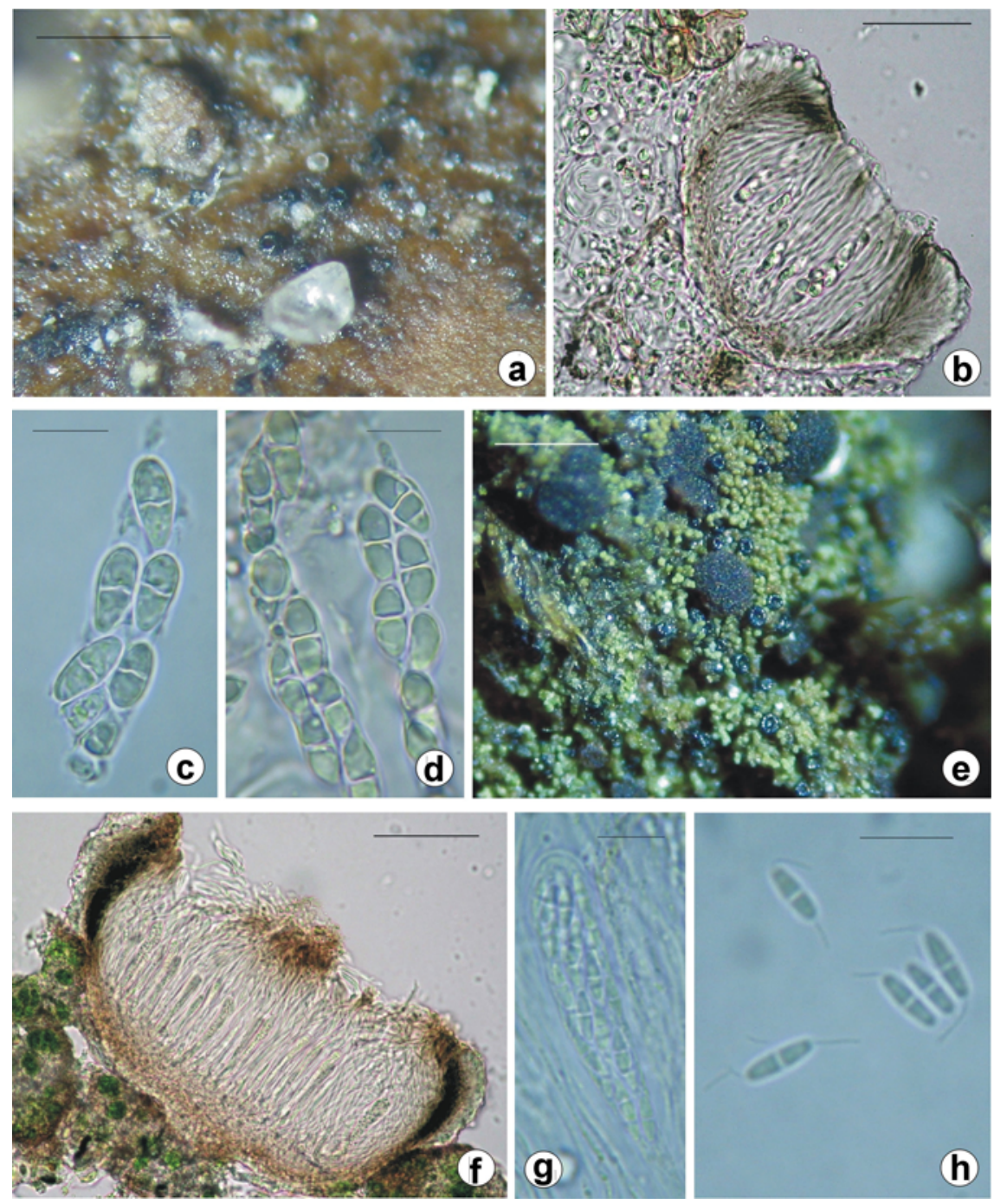

Fig. 1 Morphological and anatomical characters of examined Epigloea. a-e E. soleiformis. a Habit on Peltigera sp. (RES EH32a). b Ascomatal section (RES EH32). c-d Ascospores (Czarnota 6217 \& Czarnota 2525a). e Habit on Placynthiella dasaea (RES EH27). f-h E. urosperma. f Ascomatal section (RES EH30). g 32-spored ascus (Czarnota 6289). h Ascospores (Czarnota 6289). Scale bars: a,e 1 mm; b,f $40 \mu \mathrm{m} ; \mathbf{c}, \mathbf{d}, \mathbf{g}, \mathbf{h} 10 \mu \mathrm{m}$. 
DISTRIBUTION AND ECOLOGY. Epigloea soleiformis is usually reported as a non-lichenized algicolous fungus on bryophytes, humus, soil, rotten wood, plant debris or rocks $[3,4,6,15]$. It was also found several times on terricolous or epibryophytic lichens including: Trapeliopsis pseudogranulosa Coppins \& P. James, T. granulosa (Hoffm.) Lumbsch, Placynthiella uliginosa (Schrad.) Coppins \& P. James [6], Cladonia spp. $[3,4,16]$, Peltigera aphthosa (L.) Willd. [17] or accompanying Absconditella sphagnorum Vězda \& Poelt [4]. To date this species was not widely regarded, however, as a lichenicolous fungus. Only Zurbenko [9] based on his own collections of Epigloea soleiformis suggested that the species could not be only algicolous. In those cases E. soleiformis inhabited two representatives of Stereocaulon slightly discoloring phyllocladia and stems of their hosts. The usually present algal films were not observed. Recently also Kukwa et al. [10] included this species into the group of lichenicolous fungi inhabiting Placynthiella dasaea (Stirton) Tønsberg and P. icmalea (Ach.) Coppins \& P. James.

Some of the new collections of Epigloea soleiformis mentioned below are also made directly on the thalli of terricolous or lignicolous Placynthiella dasaea without characteristic algal film overgrowing lichens. The inhabited hosts thalli are either normally colored or only sometimes slightly discolored, thus E. soleiformis could be regarded as the facultative commensal or slightly parasitic lichenicolous fungus. In two groups of cases, with or without algal film, dimensions of ascocarps and all internal ascomatal features not differ markedly.

Chambers and David [7] based on findings from abandoned lead-zinc mining sites in Great Britain concluded that $E$. soleiformis is a metal-tolerant species. New reports from metalenriched areas of S Poland (Wyżyna Częstochowska upland) can support that hypothesis. Considering other reports made in different environmental circumstances, this fungus has a wide ecological tolerance in general.

Epigloea soleiformis is rarely reported but widespread around the world. Except records from Europe [3,4,6,7,10,13,15-18] it was found also in the subantarctic Marion Island [3], New Zealand [19], North America [20], Azores [21], Australia [7] as well as in Asia - Russian parts of Altai Mts and Sayan Mts [9]. Here it is given as new for the Western Carpathians and the Harz Mts.

SPECIMENS EXAMINED. Germany, Saxony-Anhalt, Harz Mts, Harz National Park: ca. $1 \mathrm{~km}$ N of education centre HohneHaus near Drei-Ahnen-Hohne, 51 ${ }^{\circ} 46^{\prime} 58^{\prime \prime} \mathrm{N}, 10^{\circ} 42^{\prime} 56^{\prime \prime} \mathrm{E}$, alt. ca. $400 \mathrm{~m}$, on Placynthiella dasaea on clayey soil over rootsystem of Picea abies windthrow in a managed spruce forest, 2012.05.08, leg. P. Czarnota 7482 (GPN); ibid., Heinrichshöhe, ca. $1.5 \mathrm{~km} \mathrm{SE}$ of Brocken Mt., $51^{\circ} 47^{\prime} 28.4^{\prime \prime} \mathrm{N}, 10^{\circ} 38^{\prime} 04.5^{\prime \prime} \mathrm{E}$, alt. ca. $950 \mathrm{~m}$, on Placynthiella dasaea on soil over root-system of Picea abies windthrow in an old-growth mountain spruce forest, 2012.05.08, leg. P. Czarnota 7467 (GPN). Poland, Wyżyna Częstochowska upland: Pradła village (Fryszerka settlement), on decaying thallus of Peltigera sp., 2005.08.18, leg. E. Hernik (RES EH32a-b; hb. E. Hernik); ibid., Kostkowice village, on decaying thallus of Peltigera sp., 2005.11.03, leg. E. Hernik (RES EH33a-b); ibid., Hucisko village, on decaying thallus of Peltigera sp. and Placynthiella dasaea, 2005.08.10, leg. E. Hernik (RES EH35); ibid., Zawiercie town - Skarżyce, on thallus of Placynthiella dasaea and P. icmalea, on calcareous soil in pine-birch forest, 2012.09.03, leg. E. Hernik (RES EH27; hb. E. Hernik); ibid., Zawiercie town - Pomrożyce, on Placynthiella dasaea, on humus in pine forest, 2012.08.23, leg. E. Hernik (RES EH31); Garb Tarnogórski hummock, Józefów village near
Zawiercie town, on thallus of Placynthiella dasaea overgrowing squamules of Cladonia sp., 2005.3.28, leg. E. Hernik (RES EH34); Obniżenie Górnej Warty depression, $1.5 \mathrm{~km}$ NE of Poraj village, on thallus of Placynthiella dasaea (in the company of P. uliginosa) on sandy dune in pine forest, 2012.10.25, leg. E. Hernik (RES EH28); ibid., 0.8 km NW of Dębowiec village, on thallus of Placynthiella dasaea on humus in pine forest, 2012.10.25, leg. E. Hernik (RES EH 29a-b); Carpathians, Western Beskidy Mts, Beskid Sądecki Mts, Żebracze nature reserve, alt. $840 \mathrm{~m}$, on thallus of Placynthiella dasaea mixed with Coccomyxa film over humus, 2001.07.05, leg. P. Czarnota 2525a (GPN); ibid., Babia Góra Massif, Babia Góra National Park, SE slope of Kępa Mt., forest section No. $25 \mathrm{c}, 49^{\circ} 34^{\prime} 21.4^{\prime \prime} \mathrm{N}$, $19^{\circ} 33^{\prime} 52.4^{\prime \prime} \mathrm{E}$, alt. $1210 \mathrm{~m}$, on Placynthiella dasaea on roots of fallen Picea abies within subalpine spruce forest, 2009.07.17, leg. P. Czarnota 6217 (GPN).

\section{Epigloea urosperma Döbbeler}

Sendtnera 2: 277. 1994. Fig. 1f-h.

DIAGNOSTIC CHARACTERS. Morphology similar to $E$. soleiformis, but ascocarps slightly larger, up to $0.2 \mathrm{~mm}$, with widely marked depression around the ostiolum, thus they often resemble apothecia. Asci clavate, 32-spored. Ascospores 1-septate, ellipsoid, 6-8 $\times 2.5-3.5 \mu \mathrm{m}$, with two filamentous appendages of several $\mu \mathrm{m}$ length at both rounded ends. For detailed, illustrated description see Döbbeler [8].

NOTES. Epigloea urosperma is easily recognizable by 32-spored asci (Fig. $1 \mathrm{~g}$ ) and small ellipsoid spores with long, cilia-like appendages (Fig. 1h).

DISTRIBUTION AND ECOLOGY. Contrary to other representatives of the genus Epigloea, this species is not regarded algicolous but lichenicolous. It is known only from scattered localities in Europe: Germany, Sweden, Great Britain, Switzerland, Austria, N Poland $[6,8,10,18,22]$, and recently it has been also found in South America, at one locality in Bolivia [23]. Older European collections of $E$. urosperma were usually made together with Placynthiella uliginosa. Döbbeler [8], however, in his comment for the protologue of E. urosperma mentioned Saccomorpha uliginosa-complex as the host for this species. It is possible that within this complex was also Placynthiella dasaea not well recognized at that time elsewhere (or overgrowing the true P. uliginosa), since the recent data from Bolivia [23], N Poland $[10,22]$ and the new records presented here, show that E. urosperma is confined to $P$. dasaea.

The species is presented here as new for the Carpathians. SPECIMENS EXAMINED. Poland, Równina Bielska plain, Białowieża Primeval Forest, Białowieża Forest District, forest sec. No. 494C, on thallus of Placynthiella cf. dasaea over humus on sandy soil in pine forest Vaccinio vitis-idaeaePinetum, 2002.08.12, leg. P. Czarnota 3045 (GPN); Pojezierze Południowopomorskie lakeland, Bory Tucholskie Forest, "Krwawe Doły" nature reserve, $53^{\circ} 59^{\prime} 38^{\prime \prime} \mathrm{N}, 18^{\circ} 00^{\prime} 31^{\prime \prime} \mathrm{E}$, alt. $140 \mathrm{~m}$, on thallus of Placynthiella dasaea over Pinus sylvestris stump within boggy pine forest, 2006.09.14, leg. P. Czarnota 6582 (GPN); Obniżenie Górnej Warty depression, Korwinów village near Częstochowa city, on thallus of Placynthiella dasaea over sandy soil in young Pinus sylvestris plantation, 2012.10.24, leg. E. Hernik (RES EH30); Carpathians, Western Beskidy Mts, Babia Góra Massif, Babia Góra National Park: forest section no. 6d, N slope of Sokolica Mt., $49^{\circ} 35^{\prime} 29.4^{\prime \prime} \mathrm{N}, 19^{\circ} 33^{\prime} 41.2^{\prime \prime} \mathrm{E}$, alt. $1050 \mathrm{~m}$, on Placynthiella dasaea over decaying log of Abies alba within montane fir-beech-spruce forest, 2009.08.25, leg. P. Czarnota $6287 \& 6289$ (GPN). 


\section{Conclusion}

Epigloea soleiformis is regarded here as more variable species than was originally described, but the real status and the phylogenetic affinity of all intraspecific groups which differ in the size and shape of ascospores can be confirmed by molecular evidences. The species seems to be at least occasionally lichenicolous, not algicolous as usually. It was found mainly on representatives of the genus Placynthiella (especially P. dasaea) and terricolous Peltigera. Its parasitic character manifests sometimes by a local disscolouration of the host thallus. Similarly $E$. urosperma has been confirmed here as another lichenicolous member of the genus. Both species of Epigloea were rarely reported from Central Europe to date but they are probably more widespread and frequent elsewhere. In this work E. soleiformis is presented as a new species to the Western Carpathians and the Harz Mts in Germany, and E. urosperma is reported as new to whole Carpathians.

\section{Acknowledgments}

Special thank to anonymous reviewers for their valuable comments, editorial suggestions and all language corrections improving the text. A part of this study was financially supported by the University of Rzeszów task grant No. WBR/ KAiAK/DS/5/ 2013.

\section{Authors' contributions}

The following declarations about authors' contributions to the research have been made: field studies, determination of the specimens, laboratory works, photographs, bibliography studies: $\mathrm{EH}, \mathrm{PC}$; writing the manuscript, preparing of the plate of photographs, final corrections: PC.

\section{References}

1. MycoBank fungal databases [Internet]. 2013 [cited 2013 Sep 28]; Available from: http://www.mycobank.org

2. Lumbsch HT, Huhndorf SM. Outline of Ascomycota - 2009. Myconet 14 . Fieldiana Life Earth Sci. 2010;1:1-42. http://dx.doi.org/10.3158/1557.1

3. Döbbeler P. Symbiosen zwischen gallertalgen und gallertpilzen der gattung Epigloea (Ascomycetes). In: Hertel H, Oberwinkler F, editors. Beitrage zur lichenologie. Festschrift J. Poelt. Beiheft zur nova hedwigia. Vaduz: J. Cramer; 1984. p. 203-239. (vol 79).
4. Ceynowa-Giełdon M. The genus Epigloea in Poland. Acta Mycol. 2002;37(1-2):3-11.

5. Ceynowa-Giełdon M. The alga-fungus community in the Epigloea genus at the evolution stage of lichens. Ecol. Quest. 2004;5:57-92.

6. Pérez-Ortega S, Barreno E. The genus Epigloea Zukal in the Iberian Peninsula. Nova Hedwig. 2006;83(3-4):523-531. http://dx.doi. org/10.1127/0029-5035/2006/0083-0523

7. Chambers SP, David JC. Epigloea Zukal (1890). In: Smith CW, Aptroot A, Coppins BJ, Fletcher A, Gilbert OL, James PW, editors. The lichens of Great Britain and Ireland. London: British Lichen Society; 2009. p. 392-394.

8. Döbbeler P. Epigloea urosperma (Ascomycetes) - ein neuer flechtenparasit. Sendtnera. 1994;2:277-282.

9. Zhurbenko M. New and interesting lichenicolous fungi from Eurasia. II Mycosphere. 2010;1:213-222.

10. Kukwa M, Kowalewska A, Śliwa L, Czarnota P, Czyżewska K, Flakus A, et al. Porosty i grzyby naporostowe Wdzydzkiego Parku Krajobrazowego (Pomorze Gdańskie, N Polska). Acta Bot Cassub. 2012;11:75-103.

11. Cykowska B, Flakus A. Epigloea medioincrassata (Epigloeaceae, non-lichenized Ascomycota), a species new to Poland. Pol Bot J. 2005;50:233-234.

12. Ceynowa-Giełdon M. New localities of Epigloea bactrospora and E. pleiospora in Poland. Graph Scr. 2005;17:52-55.

13. Khodosovtsev AY. New lichen genera for Ukraine. Ukr Bot J. 2005;62:170-174.

14. Kondracki W. Geografia regionalna Polski. Warsaw: Polish Scientific Publishers PWN; 2000.

15. Sérusiaux E, Diederich P, Brand AM, van den Boom P. New or interesting lichens and lichenicolous fungi from Belgium and Luxembourg. VIII Lejeunia. 1999;162:1-95.

16. Pérez-Ortega S. New records of Epigloea Zukal from Spain. Bot Complut. 2009;33:7-8.

17. Berger F. Beitrag zur kenntnis der flechten und lichenicolen pilze Islands. Acta Bot Isl. 2000;13:69-82.

18. Santesson R, Moberg R, Nordin A, Tønsberg T, Vitikainen O. Lichenforming and lichenicolous fungi of Fennoscandia. Uppsala: Museum of Evolution; 2004.

19. Fryday AM. Additional lichen records from New Zealand 32. Epigloea soleiformis Döbbeler and Fuscidea impolita (Müll. Arg.) Hertel. Australas Lichenol. 2000;47:30-31.

20. Buck WR, Harris RC. Epigloea (Epigloeaceae) new to North America. Evansia. 2002;19(3):83-84.

21. Hafellner J. A new checklist of lichens and lichenicolous fungi of insular Laurimacaronesia including a lichenological bibliography for the area. Fritschiana. 1995;5:1-132.

22. Kukwa M, Flakus A. New or interesting records of lichenicolous fungi from Poland VII. Species mainly from Tatra Mountains. Herzogia. 2009;22:191-211.

23. Flakus A, Kukwa M. New records of lichenicolous fungi from Bolivia. Opusc. Philolichenum. 2012;11:36-48. 